\title{
ToF-SIMS and Principal Component Analysis Investigation of Denatured, Surface-Adsorbed Antibodies
}

\author{
Nicholas G. Welch ${ }^{1,2}$, Robert M. Madiona ${ }^{1,2}$, Judith A. Scoble ${ }^{2}$, Benjamin W. Muir ${ }^{2}$, Paul J. Pigram ${ }^{1 *}$ \\ ${ }^{1}$ Centre for Materials and Surface Science and Department of Chemistry and Physics, School of Molecular Sciences, La Trobe \\ University, VIC, 3086, Australia \\ ${ }^{2} \mathrm{CSIRO}$ Manufacturing, VIC, 3168, Australia
}

Supporting Information

Table S1. A compiled list of known ToF-SIMS mass fragments of amino acids.

\begin{tabular}{|c|c|c|c|}
\hline Number & $\mathrm{m} / \mathrm{z}$ & Fragment Label & AA \\
\hline 1 & 30.03 & $\mathrm{CH}_{4} \mathrm{~N}^{+}$ & Glycine/Lysine \\
\hline 2 & 43.03 & $\mathrm{CH}_{3} \mathrm{~N}_{2}^{+}$ & Arginine \\
\hline 3 & 43.05 & $\mathrm{C}_{3} \mathrm{H}_{7}^{+}$ & Isoleucine/Leucine \\
\hline 4 & 44.01 & $\mathrm{CH}_{2} \mathrm{NO}^{+}$ & Asparagine \\
\hline 5 & 44.05 & $\mathrm{C}_{2} \mathrm{H}_{6} \mathrm{~N}^{+}$ & Alanine/Lysine \\
\hline 6 & 56.05 & $\mathrm{C}_{3} \mathrm{H}_{6} \mathrm{~N}^{+}$ & Lysine \\
\hline 7 & 60.05 & $\mathrm{C}_{2} \mathrm{H}_{6} \mathrm{NO}^{+}$ & Serine \\
\hline 8 & 61.01 & $\mathrm{C}_{2} \mathrm{H}_{5} \mathrm{~S}^{+}$ & Methionine \\
\hline 9 & 68.05 & $\mathrm{C}_{4} \mathrm{H}_{6} \mathrm{~N}^{+}$ & Proline \\
\hline 10 & 69.03 & $\mathrm{C}_{4} \mathrm{H}_{5} \mathrm{O}^{+}$ & Threonine \\
\hline 11 & 70.03 & $\mathrm{C}_{3} \mathrm{H}_{4} \mathrm{NO}^{+}$ & Asparagine \\
\hline 12 & 70.07 & $\mathrm{C}_{4} \mathrm{H}_{8} \mathrm{~N}^{+}$ & Arginine/Proline/Valine \\
\hline 13 & 71.01 & $\mathrm{C}_{3} \mathrm{H}_{3} \mathrm{O}_{2}^{+}$ & Serine \\
\hline 14 & 72.04 & $\mathrm{C}_{3} \mathrm{H}_{6} \mathrm{NO}^{+}$ & Alanine/Threonine \\
\hline 15 & 72.08 & $\mathrm{C}_{4} \mathrm{H}_{10} \mathrm{~N}^{+}$ & Valine \\
\hline 16 & 73.06 & $\mathrm{C}_{2} \mathrm{H}_{7} \mathrm{~N}_{3}^{+}$ & Arginine \\
\hline 17 & 74.06 & $\mathrm{C}_{3} \mathrm{H}_{8} \mathrm{NO}^{+}$ & Threonine \\
\hline 18 & 80.05 & $\mathrm{C}_{5} \mathrm{H}_{6} \mathrm{~N}^{+}$ & Proline \\
\hline 19 & 83.05 & $\mathrm{C}_{5} \mathrm{H}_{7} \mathrm{O}^{+}$ & Valine \\
\hline 20 & 84.05 & $\mathrm{C}_{4} \mathrm{H}_{6} \mathrm{NO}^{+}$ & Glutamine/Glutamic Acid \\
\hline 21 & 84.08 & $\mathrm{C}_{5} \mathrm{H}_{10} \mathrm{~N}^{+}$ & Isoleucine/Leucine/Lysine \\
\hline 22 & 86.10 & $\mathrm{C}_{5} \mathrm{H}_{12} \mathrm{~N}^{+}$ & Isoleucine/Leucine \\
\hline 23 & 91.05 & $\mathrm{C}_{7} \mathrm{H}_{7}^{+}$ & Phenylalanine/Tyrosine \\
\hline 24 & 100.08 & $\mathrm{C}_{4} \mathrm{H}_{10} \mathrm{~N}_{3}^{+}$ & Arginine \\
\hline 25 & 102.06 & $\mathrm{C}_{4} \mathrm{H}_{8} \mathrm{NO}_{2}^{+}$ & Glutamic Acid/Threonine \\
\hline 26 & 104.05 & $\mathrm{C}_{4} \mathrm{H}_{10} \mathrm{NS}^{+}$ & Methionine \\
\hline 27 & 107.05 & $\mathrm{C}_{7} \mathrm{H}_{7} \mathrm{O}^{+}$ & Tyrosine \\
\hline 28 & 110.07 & $\mathrm{C}_{5} \mathrm{H}_{8} \mathrm{~N}_{3}^{+}$ & Histidine \\
\hline 29 & 117.04 & $\mathrm{C}_{5} \mathrm{H}_{9} \mathrm{SO}^{+}$ & Methionine \\
\hline 30 & 120.08 & $\mathrm{C}_{8} \mathrm{H}_{10} \mathrm{~N}^{+}$ & Phenylalanine \\
\hline 31 & 130.07 & $\mathrm{C}_{9} \mathrm{H}_{8} \mathrm{~N}^{+}$ & Tryptophan \\
\hline 32 & 131.05 & $\mathrm{C}_{9} \mathrm{H}_{7} \mathrm{O}^{+}$ & Phenylalanine \\
\hline 33 & 136.07 & $\mathrm{C}_{8} \mathrm{H}_{10} \mathrm{NO}^{+}$ & Tyrosine \\
\hline 34 & 147.04 & $\mathrm{C}_{9} \mathrm{H}_{7} \mathrm{O}_{2}^{+}$ & Tyrosine \\
\hline 35 & 159.09 & $\mathrm{C}_{10} \mathrm{H}_{11} \mathrm{~N}_{2}^{+}$ & Tryptophan \\
\hline
\end{tabular}


A)

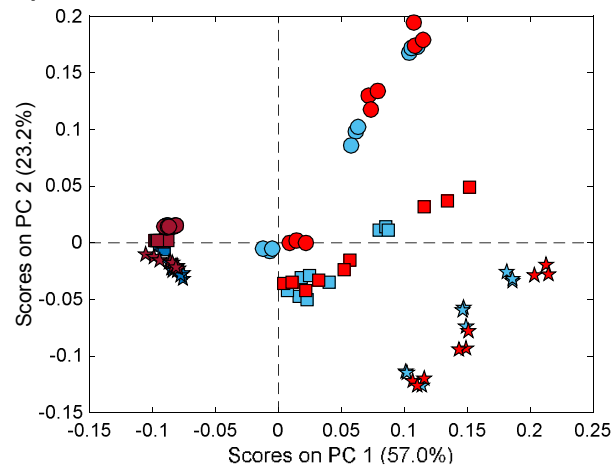

B)

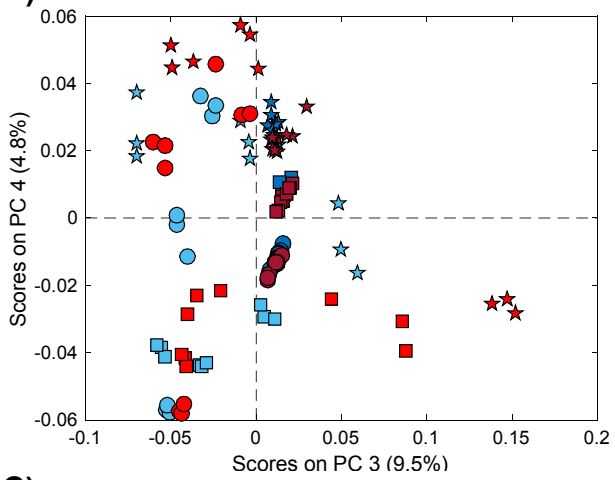

C)

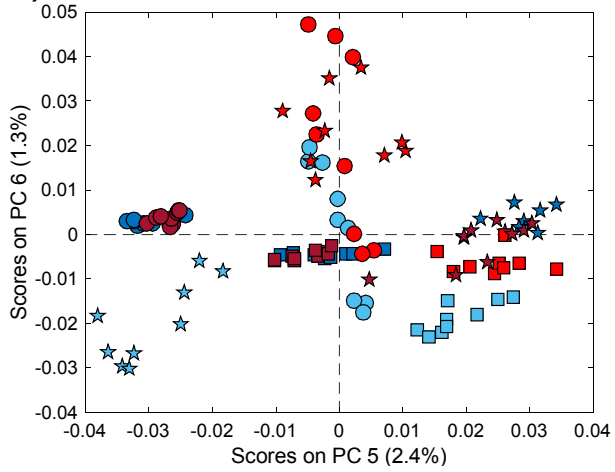

D)

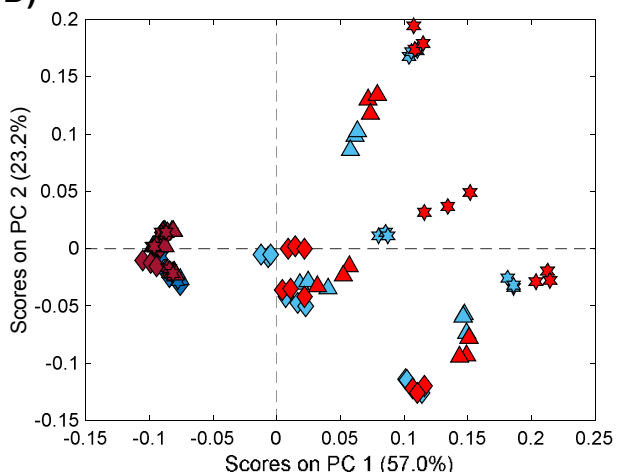

E)

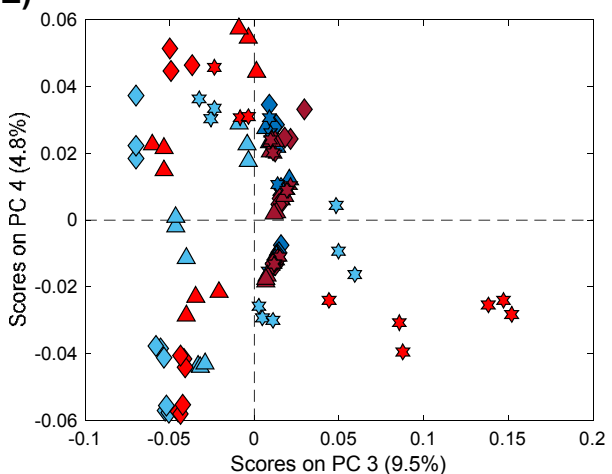

F)

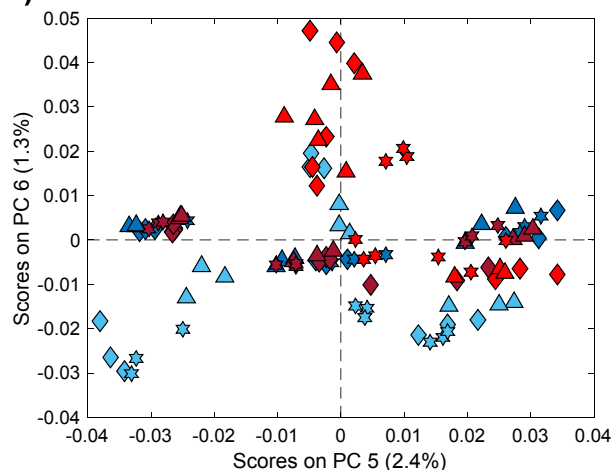

Figure S1. Principal component analysis of the whole sample set utilizing all primary-ions and the 1003 mass fragment peak list. Silicon (light) and DG (dark) substrate samples with: $\mathrm{A}-\mathrm{C}$ ) Primary-ions; $\mathrm{Bi}_{3}{ }^{+}(\bullet), \mathrm{Bi}^{+}(\mathbf{\square})$ and $\left.\mathrm{Mn}^{+}(\star), \mathrm{D}-\mathrm{F}\right)$ Protein fragments; $\operatorname{lgG}(\diamond), \mathrm{F}\left(\mathrm{ab}^{\prime}\right)_{2}(\boldsymbol{\bullet})$ and $\mathrm{Fc}(*)$. Day 0 samples shown in blue and Day 14 samples shown in red. 
A)

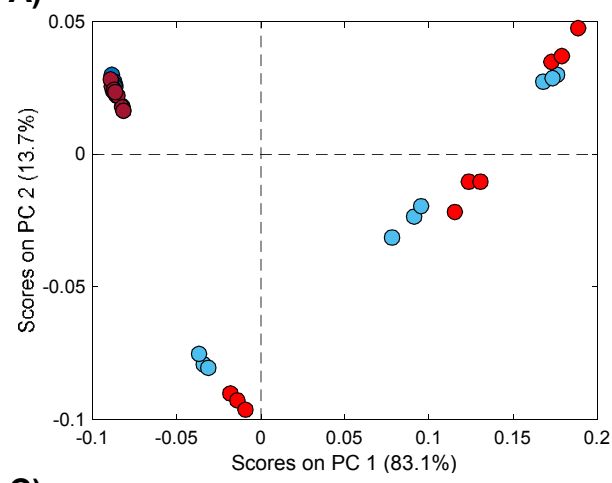

C)

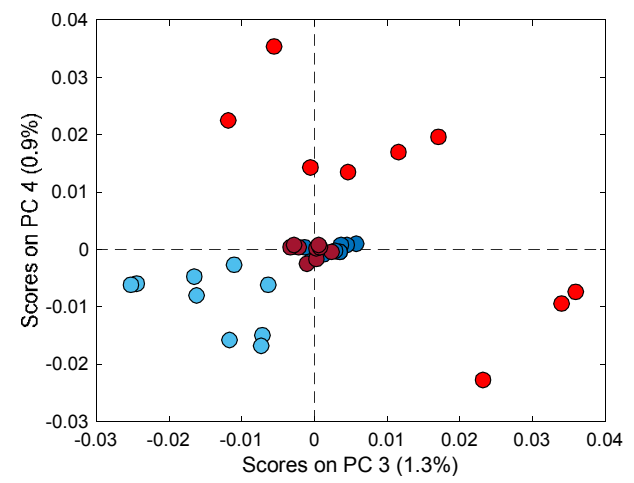

B)

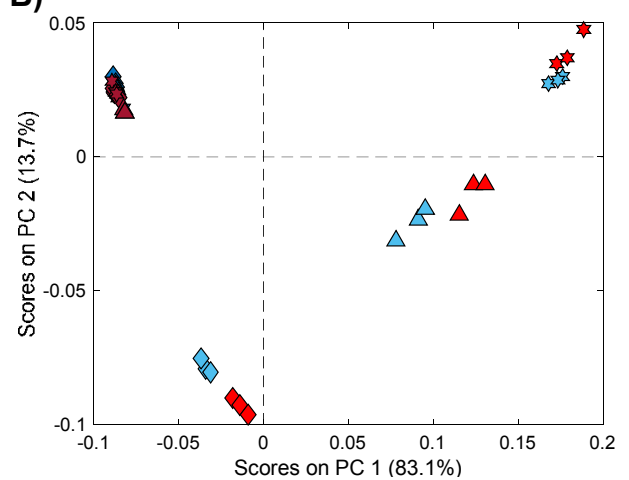

D)

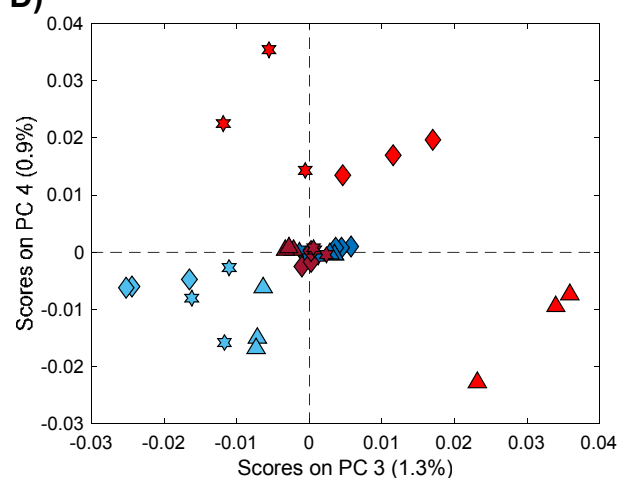

Figure S2. Principal component analysis of the whole sample set utilizing the $\mathrm{Bi}_{3}{ }^{+}$primary-ion and the 1003 mass fragment peak list. PC1 plotted against PC2 showing discrimination of; A) Si substrate (light) from DG substrate (dark) and B) protein fragments; IgG $(\diamond), F(a b)_{2}(\Delta)$ and Fc $(*)$ and, similarly for PC3 plotted against PC4 for C) and $D$ ) respectively. Day 0 samples shown in blue and Day 14 samples shown in red.
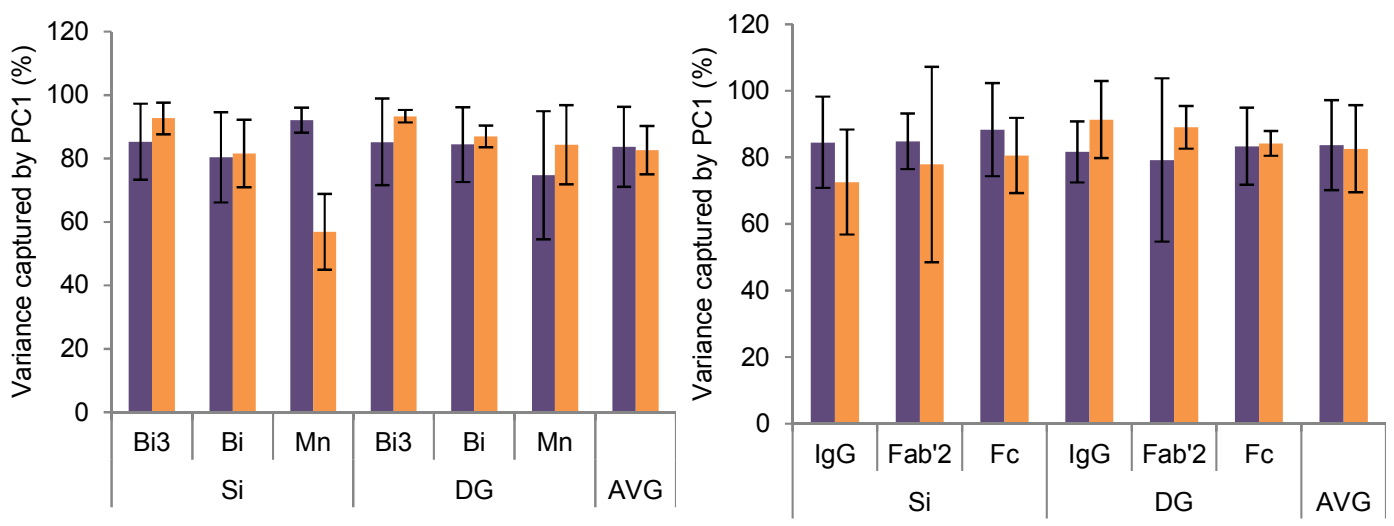

Figure S3. A comparison of the average percentage of variance captured by the first principal component, PC1 for analysis conducted with 1003 mass fragments (purple) or 35 amino acid related mass fragments (orange). Average of triplicate samples. Error bars \pm standard deviation. 
Table S2. Mass fragments loading with Day 14 for all 18 PCs (Group 1) and for other groups produced using the PC1 approach. Assignments to the mass fragments and associated deviation from exact mass for the amino acid only approach are shown.

\begin{tabular}{|c|c|c|c|c|c|}
\hline & $\begin{array}{l}\text { ToF-SIMS } \\
\text { Measured Mass }\end{array}$ & $\begin{array}{l}\text { Amino } \\
\text { Acid }\end{array}$ & $\begin{array}{l}\text { Potential } \\
\text { Assignments }\end{array}$ & $\begin{array}{l}\text { Exact Mass of } \\
\text { Assignment }\end{array}$ & $\begin{array}{l}\text { Deviation from Measured } \\
\text { Mass (ppm) }\end{array}$ \\
\hline $\begin{array}{c}\text { Group } 1 \\
\text { (18 out of } 18 \mathrm{PCs} \text { ) }\end{array}$ & - & - & - & - & (2) \\
\hline $\begin{array}{c}\text { Group } 2 \\
\text { (17 out of } 18 \text { PCs) }\end{array}$ & - & - & - & - & - \\
\hline $\begin{array}{c}\text { Group } 3 \\
\text { (16 out of } 18 \text { PCs) }\end{array}$ & & - & - & - & - \\
\hline $\begin{array}{c}\text { Group } 4 \\
\text { (15 out of } 18 \text { PCs) }\end{array}$ & - & - & - & - & - \\
\hline $\begin{array}{c}\text { Group } 5 \\
\text { (14 out of } 18 \mathrm{PCs} \text { ) }\end{array}$ & 43.0554 & $\begin{array}{l}\text { ILE/ } \\
\text { LEU }\end{array}$ & $\mathrm{C}_{3} \mathrm{H}_{7}^{+}$ & 43.0555 & -26.91 \\
\hline \multirow[t]{3}{*}{$\begin{array}{c}\text { Group } 6 \\
\text { (13 out of } 18 \text { PCs) }\end{array}$} & 72.0445 & $\begin{array}{l}\text { ALA/ } \\
\text { THR }\end{array}$ & $\mathrm{C}_{3} \mathrm{H}_{6} \mathrm{NO}^{+}$ & 72.0444 & -1.81 \\
\hline & & & $\mathrm{O}_{4} \mathrm{H}_{8}^{+}$ & 72.0423 & -30.96 \\
\hline & & & $\mathrm{CH}_{4} \mathrm{~N}_{4}{ }^{+}$ & 72.0436 & -12.91 \\
\hline
\end{tabular}

Table S3. Mass fragments loading with Day 0 for all 18 PCs (Group 1) and for other groups produced using the PC1 approach. Assignments to the mass fragments and associated deviation from exact mass for the amino acid only approach are shown.

\begin{tabular}{|c|c|c|c|c|c|}
\hline & $\begin{array}{l}\text { ToF-SIMS } \\
\text { Measured Mass }\end{array}$ & $\begin{array}{l}\text { Amino } \\
\text { Acid }\end{array}$ & $\begin{array}{l}\text { Potential } \\
\text { Assignments }\end{array}$ & $\begin{array}{l}\text { Exact Mass of } \\
\text { Assignment }\end{array}$ & $\begin{array}{l}\text { Deviation from Measured } \\
\text { Mass (ppm) }\end{array}$ \\
\hline $\begin{array}{c}\text { Group } 1 \\
\text { (18 out of } 18 \text { PCs) }\end{array}$ & - & - & - & - & - \\
\hline $\begin{array}{c}\text { Group } 2 \\
\text { (17 out of } 18 \text { PCs) }\end{array}$ & - & - & - & - & - \\
\hline Group 3 & 73.0660 & ARG & $\mathrm{C}_{2} \mathrm{H}_{7} \mathrm{~N}_{3}^{+}$ & 73.0634 & -35.62 \\
\hline (16 out of 18 PCs) & & & $\mathrm{C}_{4} \mathrm{H}_{9} \mathrm{O}^{+}$ & 73.0648 & -16.46 \\
\hline $\begin{array}{c}\text { Group } 4 \\
\text { (15 out of } 18 \mathrm{PCs} \text { ) }\end{array}$ & - & - & - & - & - \\
\hline
\end{tabular}

